\title{
Blackett on British Technology
}

\author{
Professor P. M. S. Blackett, President of the Royal Society and \\ Special Adviser to the Minister of Technology, addressed the \\ Parliamentary and Scientific Committee after lunch on February 16. \\ What follows is an extract from his address.
}

MY first comment is that I am an optimist about the future. Not, however, because I think most things are right--on the contrary, I think very many things are wrong - but, and here is an essential point, they are wrong in a way which can be understood and which can be put right reasonably quickly. As an experimental physicist, I know that the real moment of pessimism is when one cannot find out why one's apparatus will not work. As soon as one has found out what was wrong, then optimism returns, even if one has to scrap and rebuild a lot of the apparatus.

On higher education and pure scientific research, I will have little to say-mainly because I think our present system on the whole is good. Of course, there are defects. But many of the essential changes are in process of being carried out: and indeed have been under way for the past five years or so. The main changes needed are more university places, more universities trying out new methods, more emphasis in schools and universities on technology, more scientists taking up careers in industry (especially physicists), more emphasis on postgraduate studies (including management studies), closer contact of universities and industry.

As I have said, I am optimistic about the state of our universities and of fundamental science. I also, of course, recognize the great increase of government money which has made these results possible. I must confess, however, that I am concerned at the recent increase of fees for overseas students. Many of my scientific colleagues have eloquently criticized this action. In general, I agree with their main criticisms. In particular, I am worried at the possible damage to the postgraduate schools of our universities just at the time when it has become national policy to build them up. It is in the postgraduate schools of universities where the internationalism of learning bears most fruit.

Perhaps the most urgent task for many industries, in my view, is to rationalize their structure, preforably on their own initiative and without waiting for the Government, into fewer, larger and more specialized firms. These changes would, of course, bring longer manufacturing runs and so should achieve marked economies of scale. Most important of all, perhaps, the reduction in the number of firms and the increase of their size would allow a decisive increase in the available number of qualified scientists and engineers in each firm for all the stages of my chain, in particular for the building up of $R \& D$ groups of adequate size to be viable. It would also allow the best managors to be better utilized.

Of course, merging is only one way of getting larger firms quickly. The more usual method, and perhaps the more important, is by rapid growth of a single firmperhaps initially quite a small one--under first-class management. I am convinced that in many cases the Government should assist such go-ahead firms in a deliberately selective way. Though I ean understand how unpopular selective measures are in many parts of industry, I am convinced that only by some form of selective concentration of our technological, manufacturing and industrial resources in strong firms can Britain compete internationally in many advanced products. Selective financial assistance to solected firms from the Government is especially needed when the main competition comes from foreign and international firms, like many in the U.S.A., which have been heavily financed by fall-out from space or defence contracts. Obvious examples are computers, instruments, microcircuits and aireraft.

I now want to discuss some aspects of government procurement. Recently it has been realized that some of the traditional methods of procurement by central government or by state corporations and authorities could be improved if the objective were accepted of bringing into being a few really first-rate and internationally com. petitive firms.

My second criticism is a very familiar one and relates to the practice of some Government agencies of spreading their orders for some products-for instance, heavy electrical equipment-round too many firms, so perpetuating fragmentation of $R \& D$ teams or even increasing it, as well as denying the advantages of scale in manufacture.

My third criticism relates to a fairly common failure of a Government agency, when placing a development contract with a firm for some product which the Government will itself purchase for its own needs, to so modify the specification as to make the product more saleable at home and abroad.

My fourth and last criticism of the Government today -I have plenty more ready for other occasions !-relates to some of the $R$ \& D programmes carried out in government research establishments and the use made of the results. For one thing, there is often a great lack of cost-consciousness. This has provoked some industrialists to accuse some government establishments of designing gold bricks. Then, when an establishment has completed some R \& D programme it is quite usual to make the results available to all the relevant firms-in the sacred pursuit of fairness. In fact, it often happens that no British firm can profitably take it up without some degree of monopoly right in it, so no firm takes it up. The $R \& D$ is thus wasted. If and when the results are actually published, as they often are, then it is quite likely that they will be exploited first by quick-off-the-mark foreign firms.

The more general problem of the role of $R \& D$ effort in government stations and in industry raises very delicate questions. I have slowly come to the conclusion that Britain after the war inadvertently took a wrong turning when it continued to rely so much for defence and atomic energy $R \& D$ on its own government stations, rather than on industry. I believe that in the U.S.A. a bigger fraction of government funds for defence and atomic energy went to industry and less to government stations. Few would now doubt that the United States has gained greatly from the resulting strengthening of industry and the building up of very strong firms, and that Britain has lost relatively.

On the other hand, for long pay-off time projects, say. 10 to 20 years, the less commercial atmosphere of some government stations may be an advantage. A major national problem today is how to divide our total tech. nological resources between long and short pay-off investments and between government stations and industry. A high level of technological, economic and industrial statesmanship will be needed to solve this problem. 